\title{
Fundamentalisme sebagai Ideologi Transisi
}

\author{
Muhammad Idrus
}

This article explores the fundamentalism as a transition ideology. Actually religion is not only covers the doctrine the relationship between God and man, but it also gives the contribution to solve the critical problem of human being such as social, politic, culture problem in accordance with the substance of humanity. Because of the universality of religion that mentioned above, that is the ideal function of religion. In fact, the recent accidents in human life for instance, modernity and the tragedy of World Trade Center September, 11,2001 indicate that religion (Islam) does not coincide with peace horizon, so Islam is regarded as a religion of fundamentalism. According to writer that fundamentalism is a kind of self defense mechanism of the communities of religion, particularly the community of Muslim how to face the problem of politic, culture, social life etc. It will and always present in human history, but the term that refers to it depending on who gives the name to them.

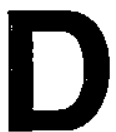
alam salah satu tulisannya, Emile Durkheim (dalam O'Dea, 1994) mengungkap tentang kebermaknaan agama bagi penganutnya, bahwa "agama memberi kesan nyaman dan tergantung". Bagi O'Dea (1994) agama memberikan sumbangan kepada sistem sosial, dalam arti pada titik kritis, pada saat manusia menghadapi ketidakpastian dan ketidakberdayaan, agama menawarkan jawaban terhadap masalah makna. Terkait dengan kepribadian manusia, O'Dea menggarisbawahi bahwa agama menyediakan dasar pokok yang menjamin usaha dan kehidupan menyeluruh, dan menawarkan jalan keluar bagi pengungkapan kebutuhan dan rasa haru serta penawar emosi manusia. Secara lebih eksplisit Dister (1982) menyebut agama berfungsi untuk menjaga susila:

Dengan begitu sebenarnya, agama bukan hanya berfungsi mengenalkan umat pada Tuhannya saja, tetapi juga secara sosial harus mengajarkan nilai-nilai yang sesuai dengan esensi kemanusiaan. Artinya, dengan agama manusia dapat secara arif mengenal siapa penciptanya, bagaimana' pola beribadah kepada penciptaanya, "dan lebih dari itu, adalah nilai-nilai tersebut harus dapat diimplementasikan dalam kehidupan sosial para pemeluknya. Di samping itu, agama juga memberikan rambu bagi proses interaksi yang lebih manusiawi.

Mencermati hal itu, tidaklah berlebihan jika agama dijadikan tumpuan akhir bagi 
Topik: Fundamentalisme, sebagai Ideologi Transisi, Muhammad Idrus

penyelesaiaan persoalan kemanusiaan baik secara sosial, politik, budaya ataupun dalam nuansa keagamaan itu sendiri. Wajah agama yang digambarkan di atas, adalah gambaran ideal fungsi.agama bagi manusia yang dapat menghantarkan manusia ke arah jalan keselamatan yang dicita-citakannya. Agama yang dapat memayu hayuning bawana, menjadikan dunia sebagai ajang pertemuan untuk membina nilai-nilai kemanusiaan.

Hanya saja, sejak peristiwa 11 September 2001 dengan tragedi pemboman gedung WTC (World Trade Center) dan Pentagon, wajah agama tidak lagi tampil dengan nuansa keteduhan, namun lebih menyiratkan kegarangan, kekejaman, dan teroris. Tertuduh ini kali adalah Osama Bin Laden ${ }^{1}$ dengan Al-Qaeda-nya, yang kemudian dicap sebagai kelompok fundamentalis Islam. Banyak pertanyaan yang dapat diajukan terkait dengan peristiwa pemboman gedung WTC itu, salah satunya adalah labelisasi fundamentalis Islam bagi kelompok Osama. Mengingat konstruk Islam, dan juga agama lainnya, menyiratkan nuansa perdamaian dan kasih bagi sesama. Sementara tampilan yang muncul begitu bertolak belakang dengan patron awalnya. Belum lagi pertanyaan tentang klaim Islam fundamentalis, yang sepertinya khas milik Islam, dan tidak muncul di agama lain?

\section{Mengapa Fundamentalisme?}

Dalam wawancara dengan kantor berita Radio $68 \mathrm{H}$ pada tanggal 14 Maret 2002, Trisno Susanto, seorang aktivis Masyarakat Dialog Anatr Agama (MADIA) Jakarta yang juga seorang teolog Kristen mengungkap, bahwa fundamentalisme merupakan kata yang digunakan untuk menyebut serial penerbitan brosur (semacam tabloid/buletin jika saat ini, pen.) yang bernama "The
Fundamentals: A Testimoni to the Truth". Penerbitan brosur yang berlangsung antara tahun 1909 hingga sekitar 1919 diprakarsai oleh para tokoh Kristen ${ }^{2}$ dari kalangan Evangelical (Injili) dan Protestan Konservatif yang berkumpul di sekolah teologi "Princetown Theological Seminary" di Amerika. $^{3}$

'Jaringan Al-Qaeda pimpinan Osama bin Laden dituduh ada di balik terror mengerikan ini. Inilah yang menyebabkan Amerika Serikat memiliki alasan untuk menyerbu Afghanistan, mendesak kubu pemerintahan Taliban yang selama ini dianggap mendukung gerakan yang dilakukan oleh Osama Bin Laden. Meski pada akhirnya pemerintahan Taliban jatuh ke tangan kelompok aliansi utara yang lebih moderat, Osama bin Laden yang dicari-cari tidak pernah ketemu.

${ }^{2}$ Tentang siapa yang memprakasai penerbitan ini ada sumber lain yang menyatakan ada dua orang kaya (sumber tersebut tidak menyebut nama) yang membiayai sebuah komisi yang diketuai oleh beberapa orang, dan terakhir diketuai oleh R.A. Torrey, yang bertugas menyusun argumentasi untuk mewakili kelompok fundamentalis. Dari sinilah kemudian diterbitkan 12 seri buku yang berjudul Fundamentals: A Testimony of the truth. Untuk kejelasannya dapat dilihat pada tulisan Steven E. Liauw (2002a), Siapakah Fundamentalis itu? di http://www.members. truepath.com/gbiagraphe/inind/artikel.html

${ }^{3}$ Transkrip wawancara Trisno Susanto dengan Kantor Berita Radio $68 \mathrm{H}$ dapat dilacak pada world wide web http://islamlib.con/ WAWANCARA/trisno1.html. Berbeda dengan Trisno Susanto, Riffat Hassan menyebut angkat tahun antara 1905 hingga 1915 untuk penerbitan risalah Fundamentals: A Testimony of the truth. Uraian tentang hal ini dapat dibaca pada: Mempersoalkan Istilah Fundamentalisme Iślam, Riffat Hassan, terjemah Dewi Nurjulianti, Ulumul Quran, nomor 3 Th. IV. 1993. Halaman 32-41. 
Melacak sejarah fundamentalisme, maka akan tersadar bahwa awal mula penggunaan istilah ini ada pada kalangan agama Kristen -protestan-. Dari sinilah kemudian dimunculkan istilah fundamentalis, yang kemudian digunakan untuk menyebut gerakan-gerakan keagamaan ${ }^{4}$-tanpa membedakan agama apapun ${ }^{5}$ - yang berusaha untuk kembali pada nash-nash kitab suci dengan pemahaman yang literal, dan eksklusif.

Ada beberapa kekhasan gerakan fundamentalis agama ini. Pertama kaum fundamental agama ini selalu mengambil posisi yang berlawanan. Kedua adanya penolakan terhadap hermeunetika. Ketiga penolakan pada budaya pluralisme dan relativisme. Keempat penolakan terhadap perkembangan historis dan sosiologis (Azra, 1993).

Kekhasan lain dari kelompok fundamentalis melihat teks-teks Bible mempunyai pengertian mutlak, jelas dan tidak berubah. Pemahaman ini pada akhirnya memunculkan argumen bahwa Kitab Suci tidak memerlukan penafsiran atau intepretasi. Pada posisi ini sebenarnya mereka secara tidak sadar telah berupaya melakukan penafsiran sendiri atas Kitab Suci itu. Tentu saja pembatasan ini menjadikan sulit bagi orang luar untuk melakukan dialog dengan kalangan fundamentalis ini.

Seperti juga telah diungkap di muka, kalangan fundamentalis menganggap bahwa ungkapan Bible sebagai satusatunya kebenaran. Pada sisi ini terjadi konflik kuat antara kalangan fundamentalis dengan para saintis, sebab bagi ilmuwan kebenaran bersifat relatif, dan hal ini tidak dapat diterima oleh kalangan fundamentalis yang menyatakan kebenaran kitab suci bersifat absolut. Sebagai sebuah gerakan, kalangan fundamentalis kerap memposisikan diri sebagai oposan terhadap sains modern. Hal ini merupakan buah sejarah panjang pertentangan kaum modernis dengan kalangan gereja. Sebagaimana dipahami, zaman modern di Eropa ditandai oleh hilangnya lembaga-lembaga politik warisan Abad Pertengahan. Kelompok bangsawan dan agamawan mulai meredup pamornya, tergeser secara drastis oleh pola pikir ilmu pengetahuan. Banyak temuantemuan ilmu pengetahuan yang bertentangan dengan doktrin-doktrin yang

${ }^{4}$ Saat ini istilah fundamentalisme lebih banyak dikaitkan dengan Islam, banyak peristiwa di tanah air, -atau yang baru saja terjadi, pemboman gedung WTC dengan menabrakkan pesawat udara seolah lebih mengkuatkan fenomena tersebut. Penggambaran kebangkitan agama di dunia Islam dengan menyebutnya sebagai gerakan Fundamentalis tentu saja tidak lepas dari bias kepentingan Barat, terlebih nuansa fundamentalis Islam cenderung berkonotasi negatif, dan menampilkan kegarangan serta kekejaman yang tidak lagi mengenal sisi kemanusiaan . Protes Riffat Hassan terhadap penggunaan istilah ini dapat dibaca di Ulumul Quran, nomor 3 Th. IV. 1993. Halaman 32-41.

${ }^{5}$ Karen Amstrong seorang biarawati Katholik penulis The Battle for God, menyatakan bahwa fundamentalisme merupakan gejala tiap agama dan kepercayaan, yang merepresentasikan pemberontakan terhadap modernitas. Menurut dia, sebenarnya sekelompok. kecil saja kalangan fundamentalis yang melakukan tindakan terorisme (Tempo, $30 / 12 / 2001)$. Pendapat ini ditentang oleh Liauw (2002) yang menyatakan bahwa Amstrong tidak memahami tentang pelaksanaan Amanat Ȧgung Tuhan Jesus melalui kesaksian dan pemberitaan Injil, dan Liauw menuduh dengan pernyataan tersebut Amstrong telah sengaja menyesatkan nalar-masyarakat. Selengkapnya baca di . Pengaruh peristiwa wtc \& pentagon, oleh Suhento Liauw pada world Wide Web: http://members.truepath.com/ gbiagraphe/article/indo/PENGARUH PERISTIWA WTC PENTAGON.htm 
sejak lama diterima masyarakat dari institusi agama. Sebagai misal temuan yang menyatakan bahwa bumi itu tidak bulat, dan beredar mengelilingi matahari yang diajukan Copernicus, ${ }^{6}$ harus berhadapan dengan doktrin gereja yang justru menyatakan sebaliknya. Atau konsep teori evolusi yang diajukan Danwin, terasa begitu kuat pengaruhnya dalam kehidupan masyarakat, dan hingga pada akhimya dianggap mengancam keyakinan Kitab Suci yang menjadi dasar teologi Kristiani.

Dari situlah dimulai konflik kalangan agamawan dengan para ilmuwan, yang mencoba memberi alternatif baru bagi proses "penemuan Tuhan". Sementara para tokoh agama tetap mempertahankan bahwa jalan kebenaran-dan yang paling benar - adalah apa yang secara tekstual tersurat dalam nash-nash kitab suci. Kritik terhadap kitab suci jelas-jelas menyalahi doktrin agama, dan itu tidak diperkenankan, sedangkan semangat ilmu pengetahuan justru dimulai dari proses keraguan untuk sampai pada satu keyakinan. Puncak keraguan kalangan ilmuwan ini sampai pada tahap meragukan Bible, bahkan sebagian sarjana bersikap lebih radikal seperti pertanyaan yang diajukan Newton tentang asal-usul agama Kristen, - merekalah yang oleh kalangan Kristen tradisional disebut sebagai kaum modernis (Ka'bah, 1993). Tentu saja penyebutan ini juga berimbas kepada mereka yang memberi label, dan mereka ditasbihkan sebagai oposan, kelompok fundamentalis.

Jadi, jika merujuk akar sejarah istilah fundamentalisme, -maka secara jelas tergambar bahwa term fundamentalisme mulanya dikenal di kalangan Kristen. Pada wacana Islam, istilah ini tidak dikenal, baḥkan kosa kata asli Indonesia tidak mengenal termonologi fundamentalisme. Istilah tersebut diadopsi begitu saja dari terminologi yang digunakan media Barat untuk menyebut kalangan Kristen yang bertahan dengan doktrin (1) kitab suci tidak dapat salah kata demi kata; (2) Ketuhanan Jesus; (3) Kelahiran Jesus dari Ibu Perawan; (4) Teori baru dalam masalah penebusan dosa; (5) kebangkitan dan kehadiran Jesus kembali secara fisik (Ka'bah, 1993).

Terlepas dari banyak protes tentang penggunaan istilah ini bagi kalangan agama lain - sebut saja Islam ${ }^{7}$ - Fundamentalisme telah menggejala dengan wajah dan format yang berbeda dengan masa awal lahimya istilah ini. Meski Hassan (1993) memprotes penggunaan istilah ini bukan hanya untuk kalangan Non-Nasrani, ${ }^{8}$

'Untuk mempertahankan keyakinannya ini pada akhirnya Copernicus harus menerima takdirnya dengan minum racun.

7Ungkapan Bernard Lewis, seorang Islamolog Yahudi yang menyatakan "sekarang sudah merupakan hal umum untuk menggunakan istilah "fundamentalis" kepada sejumlah kelompok-kelompok militan dan radikal Islam. Pemakaian istilah ini sudah mapan dan pasti diterima, tapi hal itu masih disayangkan karena dapat menyesatkan. Fundamentalis adalah istilah orang Nasrani (Hassan, 1993). Ungkapan senada diajukan oleh Frederocl M. Denny, seorang agamawan Nasrani yang menyataka, "istilah fundamentalisme muncul pada awal abad ini sebagai kerangka kerja kaum protestan konservatif di amerika untuk menunjukkan cirri suatu doktrin yang berdasarkan Kitab Injil, yang meliputi lima poin (kelahiran Jesus dari Sang Perawan, Kebangkitan fisiknya, Kitab Injil yang tanpa salah, penebusan dosa subsitusional dan kedatangan Kristus Kedua (Hassan, 1993).

8Jika memang mau diterapkan pada banyak agama lainnya, tampaknya yang sejalan dengan konsep awal fundamentalis ini hanyalah poin tentang ketidak-salahan kitab suci. Hal ini logis saja, sebab secara psikologis tidak ada satu individu yang mengaku beragama akan meyakini kitab sucinya sebagai kitab yang cacat dan salah. 
Topik: Fundamentalisme, sebagai Ideologi Transisi, Muhammāà Idrus

bahkan menurutnya juga untuk kalangan Nasrani sendiri. Istilah itu tidak tepat digunakan, sebab sangat mengecilkàn hati, bukan membawa pencerahan melainkan bentuk kebingunan dan diskriminasi. Bagi Hassan (1993) menjadi wajib hukumnya menghilangkan istilah ini dalam diskursus dialog antar agama, karena cenderung menciptakan suasana yang negatif, sehingga dialog tidak dapat berlangsung.

\section{Pencarian Ideologi Baru}

Ada hal yang menarik tentang profil kaum fundamentalis ini, Saad Eddin Ibrahim (dalam Rakhmat, 2002) mengidentifikasikan profil kalangan fundamentalis dari hasil penelitiannya terhadap 34 orang militan yang dipenjarakan pemerintah Mesir karena dituduh makar. Ibrahim menemukan bahwa usia para fundamentalis itu antara 22 dan 24 tahun, kebanyakan mereka lahir di desa atau di kota-kota kecil dan merupakan pendatang baru di kota. Setengah dari mereka tinggal di kota sendirian atau bersama teman, tetapi tidak dengan keluarganya. Dua-pertiga dari mereka berayah pegawai negeri yang berposisi menengah, lainnya berayah seorang profesional, pedagang kecil, buruh kecil dan petani kecil. Secara singkat dari sisi keluarga mereka berasal dari kalangan menengah ke bawah.

Kaum fundamentalis yang diteliti Ibrahim ini memiliki pendidikan lebih tinggi dari orangtua mereka. Duapuluhsembilan dari 34 orang tersebut adalah lulusan universitas, sisanya tamatan sekolah menengah. Hampir semua dari mereka mengambil jurusan ilmu-ilmu alamiah dan matematika. Profil ini setidaknya mengisyaratkan kelompok fundamentalis yang diteliti lbrahim memiliki motivasi dan kompetensi yang tinggi, dengan prestasi yang tinggi.
Lantas, pertanyaan yang menarik adalah mengapa mereka memilih kelompok ini atau mengikatkan diri pada kelompok ini? Padahal mereka adalah orang-orang yang memiliki kemampuan dan prestasi yang patut dibanggakan. Adakah harapanharapan psikologis yang mereka inginkan dengan memasuki kelompok ini? Pertanyaan ini menarik untuk didiskusikan, setidaknya sebagai upaya melacak latarbelakang para fundamentalis memilih aliran tersebut sebagai jalan hidupnya. Untuk menjawab pertanyaan-pertanyaan itu, setidaknya harus melacaknya dari proses modernisasi yang sejak mula ditentang oleh kalangan fundamentalis ini.

Saat ini buah modernitas telah banyak dirasakan masyarakat. Era ini hadir bak pisau bermata ganda, satu sisi banyak memberi pencerahan dan membantu manusia untuk menyelesaikan persoalan yang dihadapinya. Di lain sisi, modernisme membawa pelbagai tantangan baru, serta -tentu saja- menuntut kearifan untuk bersikap. Modernitas menghantarkan manusia untuk lebih dapat menguak rahasiarahasia Tuhan yang ada di jagat raya ini, dengan temuan ilmu pengetahuan dan teknologi yang dihasilkannya. Namun, modernitas juga membawa petaka yang tak kurang dahsyatnya. Dari rahim modernisasi muncul komunisme dan gaya hidup modern yang cenderung menganut paham materialisme-hedonisme, sebagai sebuah ideologi yang marak ditawarkan pada seluruh negara - termasuk juga negara-negara ketiga.

Paham materialisme hedonistis bukahlah hal yang baru dalam sejarah

Banyak alasan psikologis untuk membenarkan teori ini, dan selain konsep ini tampaknya sulit untuk menerapkan istilah fundamentalis ini pada lain agama, sesuai konsep awalnya. 
Topik: Fundamentalisme, sebagai Ideologi Transisi, Muhammad Idrus

;

*emanusiaan, tapi bahwa paham ini telah menyeruak begitu jauh dan mempengaruhi sikap-sikap manusia terhadap hidup begitu dalam adalah gejala yang belum lama (Maarif, 1993). Dari paham inilah tersosialisasi ideologi bahwa benda dan kesenangan duniawi adalah tujuan hidup manusia. Dalam konteks tersebut akhirnya menumbuhkan perilaku manusia yang jauh dari pertimbangan-pertimbangan moral ilahiah. Situasi inilah yang terjadi di banyak negara maju, dan menyebabkan mereka kering akan nuansa religius.

Sementara itu, komunisme menjadi ideologi lain yang tumbuh dari rahim modernitas. Ideologi ini bertolak belakang dengan ideologi kapitalis ${ }^{9}$ yang banyak dianut negara-negara Barat. Kekuatan utama ideologi ini disangga dua negara besar Rusia dan RRC. Hanya saja setelah Rusia (USSR) -yang oleh Barat dianggap sebagai lawan pada periode perang dinginruntuh, maka tolehan negara-negara Barat justru malah tertuju kepada Islam, sebagai "lawan baru". Saat itulah mulai kembali muncul luka lama peristiwa perang salib ${ }^{10}$ yang banyak menyita waktu dan perhatian dua agama besar - Kristen dan Islam-. Citra negatif Islam kembali muncul sebagai agama yang disebarkan melalui pedang. Harus diakui sejarah perkembangan Islam di jazirah Arab, baik periode awal maupun (apalagi) setelah mangkatnya Nabi, tidak terhindarkan dari lekatan kecenderungan pertumpahan darah ${ }^{11}$ dalam masa yang amat panjang (Idrus, 2002). Citra tersebut semakin menguat dengan propaganda Barat dengan media massanya, sebagai misal tulisan Michael Walzer di New Republic, edisi Desember 1980 (Rakhmat, 2002) dia mengungkap "di mana saja terjadi "pembunuhan, peperangan, dan konflik yang - melibatkan hal-hal yang mengerikan, Islam clearly played an important part" , itulah yang ditangkap dunia Barat tentang Islam.
${ }^{9}$ Berger (1982) sampai pada satu simpulan bahwa dengan bertitik tolak dari penderitaan manusiawi sebagai ukuran penilaian, kedua ideologi baik kapitalis ataupun sosialismekomunis kedua-duanya harus dianggap gagal, sekalipun masing-masing mempunyai keunggulan dan keberhasilan tertentu. Namun keunggulan dan keberhasilan tersebut harus dibayar dengan terlalu mahal (Piramida Kurban Manusia, Berger).

"Dunia Kristen Barat - Samuel Huntington menyebutnya sebagai "Western Christendom" - tampaknya cepat belajar dari sejarah Perang Salib. Barat tidak pernah melupakan Perang salib. Mereka terus menyimpan dendam terhadap umat Islam dan dunia Islam. Dalam Perang Salib yang berlangsung selama 200 tahun itu, Barat gagal menguasai Dunia Islam. Bahkan, kemudian mereka terusir dari Jerusalem oleh pasukan Islam di bawah pimpinan Shalahudin al Ayyubi. Karena itulah, Barat tetap berkeinginan merebut dan menguasai Dunia Islam dengan berbagai cara, untuk tujuan politis, ekonomis, dan keagamaan. Apalagi, Dunia Islam memang mempunyai kekayaan sumber daya alam yang melimpah, yang membuat kaum imperialis berusaha sekuat tenaga untuk menguasainya. (Huntington sebagaimana dikutip Husaini, Meletakkan pemikiran Nurcholish Madjid dalam situasi Indonesia dan dunia kontemporer, Worl Wide Web: http:/ /www.hidayatullah.com/2002/03/ihwal2.shtml

"Mencermati sejarah perkembangan Islam di tanah kelahirannya, maka terlihat betapa Islam hadir tidak lepas dari pertumpahan darah. Hal tersebut lebih dikarenakan faktor kekuasaan yang telah semakin mengukuhkan sikap-sikap saling bersebrangan di antara umat Islam sendiri. Sikap-sikap yang demikian mulai tampak dalam periode awal khalifah alrasyidin dan semakin kuat para era khalifahkhalifah Bani Umayyah. Ahmad Syafii Maarif menggambarkan masa itu sebagai masa sejarah Islam yang berkembang dalam gelimang dosa sejarah. Maarif menggugat betapa kikirnya sejarah kekhalifahan Islam pada masa itu yang hanya menyisakan Khalifah Umar bin Abdul Aziz -yang berkuasa 2 tahun lamanya- yang relatif sepi dari percikan darah (Maarif, 1993). 
Lantas, jika Barat menengok pada Islam sebagai lawan tanding baru dalam percaturan global? Sejarah telah bercerita dengan lugas, ada "rasa dendam" yang harus terbalaskan, Islam menjadi pilihan bagi proses "katarsis" " itu.

Kemajuan teknologi sebagai simbol peradaban modern tidak lagi dapat dibendung kemajuannya. Kemanfaatan modernitas pertama-tama bersifat material, dalam hal peningkatan standar hidup secara tajam, pemberantasan penyakit, penurunan angka kematian dan kenaikan angka harapan hidup. Kebermantaatan lain bersifat nonmaterial, termasuk ide kebebasan individu. Bagi Berger (1985), modernitas dipahami sebagai perubahan kehidupan manusia yang diakibatkan oleh inovasi teknologi dalam abad-abad terakhir.

Hanya saja seperti diungkap di muka, hadirnya modernitas bermata ganda dan tidak selamanya memberi peluang menyenangkan, namun juga membawa dampak yang memprihatinkan. Berger (1985) mentengarai dampak yang ditimbulkannya telah melampaui wilayah teknologi itu sendiri, telah dengan gempar mengubah seluruh pranata kehidupan yang paling global dan pribadi, serta menyusup ke dalam inti kesadaran individu.

Lebih lanjut diungkap Berger (1985) bahwa ketidakpuasan terhadap modernitas telah mengundang perlawanan dalam berbagai bentuk, kadangkala bersifat politis dan kejam, di lain waktu tidak lebih dari usaha sejumlah orang untuk menjaga "wilayah tertentu dalam kehidupan mereka" (tanda kutip dari penulis). Selain itu, modernitas banyak menuntut biaya mahal, rusaknya solidaritas tradisional, pemaksaan peran-peran baru, serta pola-pola kelembagaan, hilangnya kepercayaan terhadap nilai-nilai dan kepercayaan lama, dan dalam situasi yang paling buruk hal itu akan menjerumuskan individu ke dalam keadaan anomie - yakni keadaan tidak mengakar, tidak bertujuan, tidak lagi merasa betah didunia. Vonis terhadap gambaran manusia modern yang sudah terjatuh (fallen) memang begitu vulgar, sebagaimana diungkap Berger "Nilai-nilai supra-natural telah lenyap dalam dunia modern. Lenyapnya nilai-nilai tersebut oleh Berger diungkapkan dalam suatu rumusan kalimat agak dramatis sebagai 'Tuhan telah mati' atau 'Berakhirnya Zaman Kristus'."

Di tengah-tengah derasnya arus perubahan dan modernisasi, banyak orang memendam rasa terasing, terombangambing dan merasa tak berdaya kehilangan pegangan dan kepastian di tengah-tengah proses anomie yang sedang terjadi. Terhadap orang-orang ini, 'kebangkitan agama'13 menawarkan obat penawar (Darmaputra, 2002) . Di dalam masyarakat teknologi yang cenderung tidak manusiawi, anonimus dan impersonal, setiap sekte menawarkan dukungan psikologis melalui kehidupan berkomunitas yang akrab dan hangat.

Perubahan yang begitu cepat di masyarakat, pada akhirnya selalu diikuti dengan upaya menjaga "wilayah-wilayah"

${ }^{12}$ Makna literalnya pembersihan, dalam konteks psikologi bermakna pelepasan emosi, sehingga orang merasa lega

${ }^{13}$ Untuk kasus Indonesia, Harvey Cox dan Donald E. Smith pernah meramalkan bahwa modernisasi di Indonesia akan berimplikasi pada kebangkurtan dan tersingkirnya agama dalam kehidupan manusia, ternyata hal ini meleset dan tak terbukti. Penjelasan lebih lanjut tentang revivalisasi Islam di Indonesia dapat dibaca pada tulisan Herdi Sahrasad, Al Chaidar dan Muhammad. Muntasir tentang Reformis Islam, Negara Madinah dan Pluralisme di World Wide Web. http://www.geocities.com/madanipress/lslam Fundamentalisme dan Ideologi Revolusi.html 
Topik: Fundamentalisme, sebagai Ideologi Transisi, Muhammad Idrus

tertentu agar selalu tetap. Barangkali inilah motivasi utama kelompok fundamentalis, munculnya keinginan untuk kembali pada ajaran-ajaran kitab suci secara skriptualis. Jika melacak mula muncul istilah fundamentalis, tampaknya kondisi inilah yang terjadi. ${ }^{14}$ Artinya saat ada keinginan kelompok modernis untuk melakukan perombakan terhadap tata nilai yang telah mapan, maka sekelompok lain akan berposisi sebagai oposan, menentang perubahan itu. Hanya saja, kelompok yang kerap menggeliat saat berhadapan dengan modernitas, adalah Islam.

Modernitas yang oleh banyak pakar diidentikan dengan westernisasi harus diakui menjadi salah satu pemicu munculnya kelompok yang menginginkan kembali pada nilai-nilai kitab suci secara tekstual. Francis Fukuyama (Sahrasad, dkk., 2002) mengungkap bahwa munculnya fundamentalisme Islam (istilah ini' digunakan Fukuyama, pen) karena masyarakat muslim merasa terancam dengan nilai-nilai Barat yang diimpor ke dunia muslim, dan ada perasaan betapa martabat muslim terluka begitu dalam oleh kegagalannya untuk mempertahankan koherensi masyarakat tradisional santeri dan keberhasilan teknik dan nilai barat yang merasuk ke dunia Islam, yang membuat umat Islam mengalami alienasi, anomie, minder dan kecil hati". Ungkapan Fukuyama ini didukung oleh Fazlur Rahman (Sahrasad, dkk., 2002a) yang mentengarai munculnya fundamentalisme Islam sebagai gerakan yang menentang westernisasi dan sekularisași di dunia Islam. Fundamentalisme Islam, bagi Rahman merupakan kekuatan pembebas (liberating force) yang membebaskan pemikiran umat baik dari tradisi ataupun dominasi intelektual dan spiritual barat.

Jika pada akhirnya mereka menarik diri dan memposisikan diri sebagai oposan, maka secara psikologis dapat dibenarkan.
Sebab setiap individu memiliki model mempertahankan diri (self defence mechanism). Demikian juga pada kelompokkelompok literalis, mereka melakukan upaya "melindungi" komunitasnya, dan bersikap fanatis pada doktrin ajaran yang dianutnya, bagi mereka merupakan satu keharusan. Pada sisi ini, tidak dapat disalahkan jika muncul kelompok-kelompok "fundamentalis". Secara singkat Damaputra (2002) mengungkap bahwa kebangkitan gerakan fundamentalisme agama sebenamya dipicu oleh suatu keprihatinan etis yang besar terhadap gaya hidup modern.

Menyadari bahwa modernitas - beserta anak kandungnya - tidak dapat menyelesaikan persoalan spiritual ${ }^{15}$ yang dihadapi,

${ }^{14}$ Dengan menggunakan dialektika Hegel akan tampak bahwa fundamentalisme adalah sintesa dari suatu pergulatan antara modenitas dan permisivisme, formalitas serta. rutinitas agama-agama yang terinstitusikan. Dalam konteks ini, Naisbitt dalam Megatrends 2000, menyatakan bahwa: "Fenomena kebangkitan agama merupakan gejala yang tidak bisa dihindarkan lagi pada masyarakat yang sudah mengalami proses modernisasi, sebagai counter terhadap kehidupan yang semakin sekuler". Berpikir model paradigmatik Thomas Kuhn, maka inilah paradigma baru, yang dapat dianggap sebagai ideologi transisi bagi pemecahan masalah-masalah sosial "mereka".

${ }^{15} \mathrm{Di}$ dunia Barat, kecenderungan untuk kembali kepada dunia spiritual —meski juga perlu diingat, spiritualitas Barat cenderung lebih psikologis dibanding keilahian-ditandai dengan semakin merebaknya gerakan fundamentalisme agama dan kerohanian. Munculnya fenomena ini cukup menarik dicermati karena polanya jauh berbeda dengan agama-agama mainstream (agama formal), jika tidak ingin menyatakan justru bertentangan. Semua itu pada dasarnya, akibat kebingunan mereka dalam menentukan hidupnya. Mereka kalut dan kehilangan kendali dalam menghadapi 
Topik: Fundamentalisme, sebagai-Ideologi Transisi, Muhammad Idrus

maka pilihan-pilihan dialihkan pada institusi agama. Sebab, pada saat manusia menghadapi ketidakpastian dan ketidakberdayaan, agama menawarkan jawaban terhadap masalah makna (O'Dea, 1994). Setelah mengalami kelelahan pencarian, agama menawarkan sejumlah keteduhan, dan bak "oase" di tengah kehausan, 'agama' menghilangkan dahaga pencarian selama ini.

Terlebih saat mereka memasuki kelompok tersebut, mereka merasakan kesamaan dalam banyak hal, dan yang terpenting adalah rasa nyaman yang selama ini "mungkin" tidak mereka rasakan sebelumnya. Kondisi psikologis inilah yang kemudian menguatkan identitas diri mereka sebagai kelompok "yang berbeda" dengan laininya. Identitas dalam hal ini hendaklah dipahami sebagaimana pendapat Erikson (1963) dalam tulisannya yang menyatakan bahwa identitas bukan hanya terbatas pada dirinya sendiri saja, namun juga ada perasaan yang sama, nyaman tatkala dirinya berada pada percampuran antara dorongan dan pertahanan psikologis, juga dalam budaya dan tetangga sekitarnya, mengenal dan dikenal oleh teman sebayanya.

Dengan begitu dapat dipahami jika mereka yang mengikatkan diri pada kelompok-kelompok 'beda" tersebut merasakan situasi yang sama, rasa yang sama. Pelbagai rasa tersebut kemudian disimbolkan dalam prilaku mereka yang sama seperti makan secara bersama, menggunakan atribut-atribut yang sama, berpenampilan tisik yang sama, bertutur; dań banyak aktivitas yang dikerjakan secara kolektif dan seragam. Solidaritas yang mereka bangun begitu kokoh, yang menjadikan mereka sebagai satu kesatuan yang utuh -Islam mengisitlahkan sebagai kal jasadil wahid-.

Amat disayangkan, begitu Gordis (Darmaputra, 2002), kualitas kehidupan intra-kelompok yang menarik ini, biasanya juga diiringi dengan sikap kecurigaan ${ }^{16}$ dan permusuhan terhadap semua yang berada di luar lingkaran dalam mereka. Pada situasi ini sulit sekali bagi kelompok fundamentalis untuk berhadapan dengan wacana pluralisme ataupun multikulturalisme. Bahkan secara terang-terangkan Liauw (2002) mengidentifikasikan bahaya yang mengancam fundamentalisme masa depan, yaitu penganiayaan, kesombongan dan pluralisme. ${ }^{17}$ Menurut Liauw, menjadi" seorang

kehidupan yang semakin sulit. Jiwa-jiwa dan batin-batin mereka sibuk mencari, tapi mereka tidak tahu apa yang mereka cari. Dalam pandangan Hossein Nasr, spiritual dalam pengertian Barat cenderung dipahami sekedar sebagai fenomena psikologi. Perkembangan ini tidak dapat dilepaskan dari akibat-akibat kemanusiaan yang muncul dalam proses modernisasi, yang kemudian mendorongnya mencari tempat pelarian yang memberikan perlindungan dan kepuasan yang cepat. Hal ini diperoleh dengan memasuki kelompok fundamentalisme dan kerohanian. Bahasan menarik tentang hilangnya spritualitas Barat ini dapat dibaca pada "spiritualitas abad modern: reposisi Islam alam kancah kebangkitan agama" tulisan Ali maksum; di http://WwW.geocities.com/hotsprings/6774/j1.html.

${ }^{16}$ Menggunakan model berpikir Freudian, maka fenomena ini menjadi pembenar apa yang disinyalemenkan Freud dalam buku Totem dan Taboo, bahwa para pemeluk agama memiliki kesamaan dengan orang yang neruosis, orang yang selalu mengalami ketakutan. Untuk pembahasan lebih lanjut dapat dilacak pada Panorama Filsafat Modern, Berten; Sekelumit Sejarah Psikoanalisa, Sigmund Freud; Memperkenalkan Psikoanalisa, Sigmund Freud.

17Menurut Liauw, ketika fundamentalisme mendeklarasikan posisinya seperti tentang otoritas penuh Alkitab (2 Tim.3:16); kdosa homoseksual (Roma 1:26-27); ia akan bertabrakan langsung dengan post-modernisme 
fundamentalis bukanlah hanya memasang sebuah label. la adalah suatu ekșposisi yang teguh dan komitmen pada suatu posisi theologi, dan secara khusus, pada pemisahan personal dan eklesiatikal. la adalah penerapan doktrin dalam semua aspek kehidupan. Dengan rasa kecewanya lebih lanjut diungkap Liauw, saat ini ada sebagian orang yang mempromosikan fundamentalisme yang lebih lunak dan kurang menyolok, yang telah meninggalkan komitmen-komitmen mereka pada deklarasi dan praktek-praktek fundamentalisme.

Pada lain sisi, mereka mencoba menghadirkan konteks sejarah masa lalu, dalam nuansa kekinian. Cerita-cerita masa lalu kembali dihidupkan, lantas diintepretasikan untuk masa kini. Dalam model kelompokkelompok Islam misalnya ditunjukkan dengan cara mereka berpakaian model jubah, berhijab (di Indonesia disebut jilbab), bercadar makan dengan tiga jari, warna pakaian semuanya merujuk pada figur yang diidealkan, Nabi dan para sahabatnya. Sebab, bagi mereka jelas bahwa zaman yang ideal adalah zaman yang dibina langsung oleh para Nabi-nabi, sehingga segala bentuk yang tidak sesuai 'maunya' mereka singkirkan atau jika mungkin justru memusnahkannya.

Kerinduan pada masa lalu inilah yang terkadang menjadikan kelompok ini bukan hanya memposisikan sebagai bersebrangan, namun juga eksklusif'1 ${ }^{18}$ terhadap orang atau kelompok lain, meski mereka dalam agama yang sama. ${ }^{19}$ Kecenderungan bersikap ekslusif sebenarnya lebih dimaksudkan untuk menjaga keutuhan kelompok dan komunitas mereka sendiri, di samping untuk tidak tertulari secara ideologis. Meminjam istilah yang digunakan Erikson (1963) mereka memiliki komitmen yang kuat di antara mereka untuk saling menjaga. Komitmen yang mereka buat ini pada akhirnya akan menumbuhkan sikap militan, tatkala kelompok mereka dihadapkan pada satu pilihan..$^{20}$ Militansi anggota kelompok ${ }^{21}$

dan multikulturalisme. Dengan penuh pesimis Liauw mengungkap bahwa moralitas, kebenaran, kejujuran dan karakter adalah kualitas-kualitas yang tidak lagi dihargaj oleh standar-standar hari ini. Dunia telah melupakan bahwa moralitas pribadi menentukan kebijaksanaan publik, dan slogan live and let live - hidup dan biarkan hidup-telah menjadi filosofi yang mendasar. Ketika hal itu dipertemukan dengan fundamentalisme, maka tidak ada tempat bagi absolutisme seorang fundamentalis.

${ }^{18}$ Eksklusivisme biasanya dipahami sebagai respons tradisional sebuah agama terhadap hubungannya dengan agama-agama lain, yang memandang agama lain dengan akcamata agamnya sendiri yang didukung oleh penafsiran yang sempit atas doktrindoktrin keagamaan yang tertulis dalam kitab suci. Sikap ini biasanya dipegang teguh oleh kaum fundamentalis (Ruslani, 2002).

${ }^{19}$ Kerap ditemukan adanya kelompokkelompok yang serta merta "mengkafirkan" orang-orang atau kelompok yang berada di luar kelompok mereka. Atau dalam perilaku tertentu terlihat mereka begitu "berhati-hati", sehingga misalnya setelah bersalaman dengan orang di luar kelompok mereka, langsung mencuci tangan, atau dengan segera membersihkan alat-alat yang disentuh mereka yang bukan dari kelompoknya. Bagi mereka orang "luar kelompok" mereka adalah "najis" belum disucikan.

${ }^{20}$ Sebagai contoh, misalnya kasus David Koresh dengan Clan Davidian-nya, yang membakar diri setelah dikepung tentara Amerika, atau Pendeta Jim Jones yang mengajak jama'ahnya bunuh diri secara massal di hutan, atau kasus sekte sesat Ashahara di Jepang yang membunuh massa di jembatan kereta api bawäh tanah.

'Sebenarnya militan bukan hanya milik kelompok fundamentalis saja, setiap kelompok akan memiliki rasa militan tatkala berhadapan dengan kelompok lain, atau saat ingin 
ini juga setidaknya tumbuh karena dorongan-dorongan millenarisme (mesianisme).

Fungsi sebuah gerakan millenarisme adalah memberikan harapan-harapan kepada para anggotanya yang berakar pada kebudayaan tradisional dengan menegakkan satu kekuasaan baru, yang lebih efisien dan lebih diterima dibandingkan dengan kekuasaan yang ingin ditumbangkannya. Sebagai misal untuk masyarakat Indonesia, mitos kedatangan Ratu Adil menjadi mitos abadi yang menjadi penyejuk dan juga pendorong para pengikutnya untuk melakukan pelbagai aktivitas, bahkan dari ide inilah mereka siap untuk menjadi martir demi tercapainya cita-cita organisasi.

Secara psikologis semua rasional yang diajukan kaum fundamentalis ini logis, bahwa individu harus memiliki identitas hal itu jelas. Identitas adalah perangkat hidup yang tidak dapat ditawar, tanpa ini semua orang akan mengalami kesulitan untuk memposisikan dirinya siapa? Di mana? lantas dari identitas akan memunculkan komitmen, hal itu juga logis. Sebab salah satu indikasi kemapanan kepribadian seseorang adalah kemampuannya dalam membentuk komitmen-komitmen dengan orang-orang yang ada di sekitamya (Erikson, 1963). Dari sisi kejiwaan ini tampak logika yang diajukan kelompok fundamental mendapat pembenar.

Hanya saja perlu dipahami, bahwa pada kenyataannya dimensi psikologis umat dari gerakan fundamentalisme ini terkadng terabaikan. Adanya penekananpenekanan berupa indoktrinasi dalam proses penerimaan ideologi fundamentalis ini terkadang dilakukan dengan terus menerus menekan alam bawah sadar seseorang. Tentu saja jika hal ini benar, maka fundamentalisme akan mengalami kegagalan saat individu-individu mengalami pencerahan secara komunal. Jika sudah demikian, fundamentalisme yang semula dianggap sebagai ideologi alternatif, tatkala dipertentangkan antara agama dan modernisisasi, akan kembali mengalami jalan buntu untuk menyelesaikan persoalan yang dihadapi komunitasnya. Lagi-lagi sebagai pembenar, para elite kelompok ini menekankan pada para pengikutnya untuk percaya dengan tanpa bertanya. Lantas jika demikian, benarkah saat itu fundamentalis menjadi sebuah jalan hidup, jika si pelakunya sendiri tidak tahu tujuan akhir dari aktivitasnya?

Pertanyaan berikutnya adalah, manakala sejarah bercerita lain, fundamentalisme dianggap justru menurunkan nilai-nilai kemanusiaan $^{22}$ dan mereka mulai bosan dengan ideologi ini, kira-kira bisakah diterima neo-fundamentalime -yang saat ini juga sudah mulai tampak - sebagai ideologi pengganti oleh para penganut fundamentalisme tradisional? Dan, jika neo-fundamentalisme pada akhirnya juga tidak lagi disepakati oleh banyak kalangan, maka apalagi nama yang akan kita berikan untuk menyatakan bahwa kita tetap fundamentalis sejati? maksud penulis, bagaimana kita menyebut orang yang ingin tetap mempertahankan kemurnian nash-nash (ayatayat) dari Kitab sucinya dengan gigih?

menunjukkan identitas kelompoknya. Kaum sekuler, komunis, nasionalis, apapun label yang disandangnya harus memiliki rasa ini. Jadi salahkah mereka bersikap militan? Ya, manakala militansi ini diwujudkan dalam sikap agresi pada kelompok yang dianggapnya bersebrangan, selama itu hanya mempertahankan ideologinya, ya sah-sah saja.

${ }^{22}$ Karena fundamentalisme ini memberi peluang untuk menyingkirkan orang-orang yang tidak sepaham dengan mereka, dengan jalan apapun, termasuk membunuh. Yang bagi komunitas agama manapun hal tersebut dilarang. 
Topik: Fundamentalisme, sebagai Ideologi Transisi, Muhammad Idrus

Fanatik? atau kaku? mungkin perlu dicarikan satu padanan kata yang sesuai dengan fundamentalis dalam bahasa indonesia yang 'lebih halus' sebagaimana biasa kita lakukan untuk banyak hal.

Setidaknya hal tersebut mengisyaratkan bahwa fundamentalisme akan selalu hadir dalam panggung sejarah umat manusia. Hanya saja nama yang diberikannya berbeda pada setiap episodenya, tergantung siapa yang memberi nama pada mereka.

\section{Bacaan}

Azra, A. 1993. Fenomena Fundamentalisme Dalam Islam: Survei Historis dan Doktrinal. Ulumul Quran. Nomor 3. Th, IV. 1993. Halaman 18-24.

Berger, P.L., 1982. Piramida Kurban Manusia: Etika Politik dan Perubahan Sosial. Penterjemah A. Rahman Tolleng. Jakarta: LP3ES.

Berger. P.L., dan Kellner, H., 1985. Sosiologi Ditafsirkan Kembali: Esei tentang Metode dan Bidang Kerja. Penterjemah Herry Joedino. Jakarta: LP3ES.

Bertens, K. 1987. Panorama Filsafat Modern. Jakarta: PT. Gramedia.

Darmaputra, E., 2002. Kebangkitan Agama dan Keruntuhan Etika. Retrieved from World Wide Web. Http:// www.pgi.or.id/balitbang/bal_06/ 02_saa_xvii/02.htm/.31 Mei 2002.

Dister, N.C. 1982. Pengalaman dan Motivasi Beragama: Pengantar Psikologi Agama. Jakarta: Lappenas.

Erikson, E.H. 1968. Identity: Youth and Crisis: New York: W.W. Norton \& Company. Inc.

Freud, S. 1986. Sekelumit Sejarah Psikoanalisa. Penterjemah K. Bertens. Jakarta: PT. Gramedia.
1991. Memperkenalkan Psikoanalisa. Penterjemah K. Bertens. Jakarta: PT. Gramedia Pustaka Utama.

Hassan, R. 1993. Mempersoalkan Istilah Fundamentalisme Islam, terjemah Dewi Nurjulianti, Ulumul Quran, nomor 3 Th. IV. 1993. Halaman 32-41.

Husaini, A. 2002. Meletakkan pemikiran Nurcholish Madjid dalam situasi Indonesia dan dunia kontemporer. Retrieved from World Wide Web. http://www.hidayatullah.com/2002/ 03/ihwal2.shtml

Idrus, M. 2002. Pemimpin Islam: Makhluk Langka? Jurnal Hukum Islam AlMawarid. Halaman 73-80. Yogyakarta: FIAI UII Yogyakarta.

Ka'bah, R. 1993. Modernisme dan Fundamentalisme Ditinjau dari Konteks Islam. Ulumul Quran. Nomor 3. Th, IV. 1993. Halaman 25-31.

Liauw, S. 2002. Pengaruh Peristiwa WTC \& Pentagon. Retrieved from World Wide Web.http://members. truepath. com/gbiagraphe/article/indo/ PENGARUH_PERISTIWA_WTC_ PENTAGON.htm

Liauw, S.W. 2002a. Siapakah Fundamentalis itu? Retrieved from World Wide Web http://www. members. truepath.com/gbiagraphe/inind/ artikel.htm/ 31 Mei 2002.

Liauw, S.W. 2002b. Tiga Bahaya yang Mengancam Fundamentalisme Masa Depan. Disadur dari Majalah Front Line. Retrieved from World Wide Web http://www.members. truepath. com/gbiagraphe/inind/ tiga_Bahaya.html 31 Mei 2002.

Maarif. A.S. 1993. Peta Bumi Intelektualisme Islam di indonesia. Bandung: Mizan. 
Topik: Fundamentalisme, sebagai Ideologi Transisi, Muhammad Idrus

Maksum, A. 2002. Spiritualitas Abad Modern: Reposisi Islam dalam Kancah Kebangkitan Agama. Retrieved from World Wide Web http:/ /www.geocities.com/HotSprings/ 6774/j-1.html. 31 Mei 2002.

Naisbitt, J., Aburdene, P., 1999, Megatrend 2000. Jakarta: Binarupa Aksara.

O'Dea, T. F., 1994, Sosiologi Agama: Suatu Pengenalan Awal. Terjemahan Tim Yosogama. Jakarta: PT. Raja Grafindo Persada.

Rakhmat, J. 2002, Fundamentalisme Islam: Mitos dan Realitas. Retrieved From WorldWideWeb.Http:/ /www.pesantrenonline.com/artike// detailartikel.pphb3?artikel=98 31 Mei 2002.

Ruslani, 2002, Menuju Humanisme Agama-agama. Retrieved From WorldWideWeb.Http:// www.pesantrenonline.com/artikel/ detailartikel.php3?artikel=119. 31 Mei 2002.

Sahrasad, H., Al-Chaidar., Muntasir, M. 2002a. Fundamentalisme Islam, Barat dan Kita. Retrieved From: World Wide Web.' http://www.geocities.com/ madanipress/lslam Fundamentalisme dan Ideologi Revolusi.html

Sahrasad, H. Al Chaidar., Muntasir, M. 2002b. Reformis Islam, Negara Madinah dan Pluralisme. Retrieved From: World Wide Web. http:// www.geocities.com/madanipress/ Islam Fundamentalisme dan Ideologi Revolusi.html

Susanto, T. 2002, Fundamentalis Kristen Merebak Kuat. Retrieved from world. wide web http://islamlib.con/ WAWANCARA/trisno1.html $31 \cdot \mathrm{Mei}$ 2002

Tempo, 30 Desember 2001. 